\title{
Economic Crisis and International Migration. What the EU Data Reveal?
}

Crise économique et migration internationale. Ce que les données de l'UE révèlent?

Crisis Económica y migración internacional. ¿Qué revelan los datos de la Unión Europea?

\section{Anne Herm and Michel Poulain}

\section{(Q) OpenEdition}

\section{Journals}

Electronic version

URL: https://journals.openedition.org/remi/6171

DOI: $10.4000 /$ remi.6171

ISSN: $1777-5418$

\section{Publisher}

Université de Poitiers

\section{Printed version}

Date of publication: 1 December 2012

Number of pages: $145-169$

ISBN: 979-10-90426-06-1

ISSN: 0765-0752

\section{Electronic reference}

Anne Herm and Michel Poulain, "Economic Crisis and International Migration. What the EU Data

Reveal?", Revue européenne des migrations internationales [Online], vol. 28 - n4 | 2012, Online since 01 December 2015, connection on 14 April 2022. URL: http://journals.openedition.org/remi/6171 ; DOI: https://doi.org/10.4000/remi.6171 


\title{
Economic Crisis and International Migration. What the EU Data Reveal?
}

\author{
Anne Herm ${ }^{1}$ and Michel Poulain ${ }^{2}$
}

\section{Introduction ${ }^{3}$}

The global financial crisis, which began in the second half of 2008, has led to a downturn in the global economy and to economic recession. During such economic downturns, foreign migrants are often the most vulnerable category of workers, which can result in changes in the volume and direction of international migration flows (IILS, 2009).

International migration is a widespread phenomenon in the European Union (EU), not only characterised by large immigration flows from outside its borders, but also by migration from one member state to another. Migration within the EU, from 'new' EU 12 countries ${ }^{4}$ to 'old' EU 15 countries $^{5}$, represents a relatively large proportion of recent inflows in some EU countries. As with immigration flows originating outside the EU, this intra-EU flow of immigrants is likely to be highly responsive to the economic situation. Because the EU international migration flow consists of migrants from various backgrounds, not only the motives but also the level of effort expended to migrate will vary between different groups of migrants. In the context of the economic crisis, these differences might have a larger or smaller impact on migration decisions for new immigrants as well as for those confronting the issue of whether to remain or return to their home country.

The aim of this study was to investigate the possible impact of the recent economic crisis on international migration flows in Europe by examining the available data. For this analysis, data disseminated by Eurostat, the OECD and ILO proved to be useful in addition to some data collected in national statistical databases.

1 Estonian Institute for Population Studies, Tallinn University, P.O. Box 3012, 10504 Tallinn, Estonia; anne.herm@gmail.com

2 IACCHOS, Université catholique de Louvain, Maison Georges Lemaitre, boulevard Devreux 6, 6000 Charleroi, Belgium; michel.poulain@uclouvain.be

3 Acknowledgments: This study was supported by Grant No. 8325 from the Estonian Science Foundation.

4These are the 10 member states that joined the EU in May 2004 plus Bulgaria and Romania, which became members in January 2007.

5 These are the 15 member states that formed the EU prior to May 2004. 


\section{Recent Findings on the Economic Crisis and International Migration}

As noted by Coleman (2008), it is well known among demographers that, compared to other fields of demography, international migration presents "the least satisfactory theory, its trends are by far the most volatile, and its future by far the most difficult to forecast". It is not easy to find pertinent and reliable data for assessing the possible impact of the recent economic crisis on international migration. Nevertheless, available data should not be ignored and its validity and usefulness represents the main challenge of this study.

Numerous articles have already discussed the impact of the recent financial crisis on the levels of international migration flows (Awad, 2009; Beets and Willekens, 2009; Castles and Miller, 2009; GMG, 2009; Martin, 2009a; Sward, 2009), and several authors have considered possible lessons learned from the impact of past economic crises on international migration. The so-called "buffer theory" that posits immigrants as tools for smoothing labour market fluctuations (bringing in temporary workers during labour shortages and sending them home during economic downturns), appears not to be valid. According to that theory, unemployment can be "exported", enabling the indigenous population to remain employed, and temporary migrants are not expected to become permanent settlers (Dobson et al., 2009). They concluded that the major reasons why the buffer theory did not apply to Europe during the 1960s and 1970s are equally relevant to the current situation.

Even if the lessons of the past could help us to understand the current situation, it is thought that the recent crisis, the worst in half a century, is likely to affect international migration differently (Martin, 2009a and 2009b). Just before the recession spread around the world in 2008, the number of migrants was at record levels, and many analysts expected this growth to continue (Martin, 2009a: 688). However, flows of labour from poorer to richer countries have slowed and in some cases reversed due to the recession, and according to Martin (2009a and 2009b), it is not clear that migration will resume its upward trajectory during the economic recovery (Martin, 2009a: 688).

Castles (2009) distinguishes the short- and long-term effects of the crisis on migration and integration. The short-term effects are: (i) reduced migration flows to developed countries in response to fewer job opportunities, (ii) an increase in the propensity for some migrant workers to return to their homelands in reaction to unemployment or lower earnings, (iii) attempts by governments to provide incentives for unemployed migrant workers to leave, (iv) large declines in irregular migration, (v) reduced remittances sent by migrant workers, and (vi) increased hostility towards migrants on the part of host populations. This article is mainly concerned with the two first effects, as they are expected to be more immediate.

According to the OECD, an economic influence on international migration might be a loss of motivation to migrate as a result of increased unemployment of non-nationals relative to the indigenous population. The fallout from the financial crisis has led to particularly high unemployment that has made it significantly harder for migrants to find work in a foreign country, often without 
a social safety net to support them. As a consequence, international immigration to developed countries has fallen during the economic crisis. The decrease in the inflow of immigrants was about $6 \%$ in 2008 after five years of average annual increases of $11 \%$, and more recent national data suggest that migration numbers fell even further in 2009 (OECD, 2010a).

An ILO report by Awad (2009) states that the unemployment of the foreignborn is the key economic indicator that has an impact on immigration flows. $\mathrm{He}$ found a strong negative relationship between unemployment and the level of non-national immigration. A correlation in the same direction was found for the emigration of non-nationals; the relationship between unemployment and emigration for nationals was also negative and more pronounced (Dobson et al., 2009). If growth slows and jobs are lost, foreign migrants may no longer be needed and those migrants already in low-growth destination economies may reasonably be expected to return home (Skeldon, 2010). However, emigration or return migration of non-nationals during a downturn will depend on the economic conditions in both the sending and receiving countries. Large wage and opportunity differentials still exist between sending and receiving countries, suggesting that the recession is unlikely to result in substantial proportions of immigrants returning home. Those migrants already in countries of destination, either legally or illegally, are not necessarily interested in leaving even if the economic situation has become difficult. Unwillingness to return to their countries of origin can be reinforced by the fear that they may not be able to re-enter if they leave because of tightened immigration controls (Awad, 2009; Fix et al., 2009). Papademetriou et al. (2009) proposed a number of factors that could affect the propensity of migrants to leave the country during a downturn. In the $\mathrm{EU}$, "the increasing trend towards social justice for migrants led to a growing concern with integration and the incorporation of migrants into the population as a whole" (Dobson et al., 2009: 9), and there is no reason to believe that this will change in the current downturn. Migrants who have invested large sums of money to migrate to countries with advanced economies in order to earn higher wages are likely to try to wait out the crisis (Sward, 2009). Some first indications relative to the possible impact of the economic crisis show increasing return migration from some specific destinations, but Ratha et al. (2009: 4) write that "there is little evidence of return migration as a result of the financial crisis in the US and Europe".

In fact, the current crisis is not an event which has affected all EU Member States in the same way, and every country in the EU exhibits a unique migration process. The impact of the crisis on international migration may vary across countries. In the EU, the sectors of the economy occupied by migrant workers are not universal and such differences may influence the impact of the crisis. Awad (2009: 20) provides the following example: in the Czech Republic, Germany and Italy, migrant workers are employed in manufacturing durable goods, including automobiles. "A decrease in global demand for cars and other manufactured goods means large job losses for workers in general, and for migrants in particular." By contrast, in the Nordic countries and the Netherlands, many migrant workers are employed in the health and social work sectors where the impact of the crisis seems to be less severe. Country-specific actions also affect migration calculus; for example, the host country's visa processing system affects the likelihood that flows will respond to economic factors (OECD, 2009). Decreasing 
trends for flows into major immigration countries and those originating from the developing world are not surprising, as governments all around the world are closing their borders and encouraging return migration. For migrants who stay in the host country, unemployment is rapidly rising and working conditions are worsening (World Bank, 2009). These factors influence the likelihood that an economic downturn in immigrant-receiving countries will affect migrant inflows (Papademetriou et al., 2009). As noted by Dobson et al. (2009), economic difficulties have less impact on migration for family reasons, and that could partially obscure the real impact of the economic crisis on international migration flows.

The impact of the economic recession also varies for groups who have different reasons for migrating, and who will face different barriers in doing so. As explained by Lemaître (OECD, 2010b), compared to the drop in regulated migration from outside the EU, it is free movement within the EU which has decreased the most substantially. This decline in intra-EU mobility can be seen as a reaction to the large flow that occurred in previous years from Poland, the Baltic States, the Czech Republic, Slovakia, Hungary, Bulgaria and Romania to western EU countries. This migration flow is likely to be highly responsive to the economic situation for several reasons: (i) it is strongly labour-motivated, (ii) there is no visa requirement for EU citizens, and (iii) migrant workers face no barriers to returning to the host country in the future (Awad, 2009). Nevertheless, even if EU citizens may freely enter and stay in other EU Member States, as migrants and foreigners in the destination country, they may be equally affected by the consequences of the economic crisis.

The economic crisis is considered to be having the strongest impact on the temporary immigration of workers. Among them, "unauthorized immigrants represent the flows most closely linked to the economy, and thus the ones most likely to fall in poor economic times" (Fix et al., 2009: 2). Papademetriou et al. (2009) also think that illegal immigration is responsive to economic cycles both in host and source countries. Returning to the country of origin is often not an option for illegal migrants (Frontex, 2009). "Since irregular migrants move through networks and tend to rely on information and support from previous migrants, potential migrants quickly learn of the lack of work opportunities during recession [and may change their destination or postpone their emigration plans]. [...] Moreover, irregular migrants, unlike those having residence and work permits, generally lack entitlements to welfare support, and have little motivation to come to a destination country or to stay there if work is not available. Finally, destination countries tend to tighten up border control measures and campaigns to identify and deport irregular migrant workers in times of recession" (Castles and Miller, 2010: 6). Unfortunately, data on illegal migration are scarce, but asylum data allows unregulated migration trends to be partially identified.

The long-term effects of the recent economic crisis may turn out to be rather different from the short-term effects that have already been observed. The lessons learned from historical precedents (the crises of 1930, 1973 and 1997) show that the final effects of economic downturns on migration are complex and hard to predict. When economic conditions deteriorate in rich countries, they may be even worse in poorer countries of origin, and the motivation to migrate may be stronger than before. Moreover, global economic inequality and the 
demographic imbalances between the ageing populations of the North and the large cohorts of working age in the South will remain important factors in generating future migration (Castles and Miller, 2009). Following OECD prognoses, as the recovery proceeds, migrants will once again be needed to fill labor and skill shortages (OECD, 2010a). If the downturn remains moderate or light, many of the factors that reduced the incentives for non-nationals to immigrate and caused immigrants to return home during the downturn should eventually reverse after economic conditions improve. As Papademetriou et al. (2009) commented, it is expected that in the long term, the underlying drivers of migration will not change significantly after the downturn. As noted by Beets and Willekens (2009) "history tells that an initial response in international migration is likely to be followed relatively soon by a situation back to normal".

\section{Data and Methods}

According to the literature mentioned in the previous section, among the most widely available indicators, unemployment is the most relevant to changes in international migration flows. An increase in that indicator can make immigration to a particular country less attractive, while losing one's job can reinforce return migration. The seasonally adjusted unemployment rates for 2007-2009 used in this study were extracted from ILO Laborsta and Eurostat databases.

Of the three demographic components, "data on migration are far below the quality of those on birth and death and [...] a depressingly large literature is devoted to the complexities and difficulties of migration data" (Coleman, 2008: 453; see also Poulain et al., 2006; Raymer and Willekens, 2008; and De Beer and Willekens, 2010). As expressed by Skeldon (2010), "perhaps the major difficulty in arriving at an assessment of the impact of the crisis on migrations is the lack of reliable and timely data. Data on migration in general tend to be problematic. This is even starker in the case of such a recent event as the crisis".

The reliability and timeliness of the data is the key problem when analyzing the possible impact of the economic crisis on international migration flows. While migration is more responsive to short-term economic factors than other demographic events, rapid information on changes in migration flows does not exist.

Annual Eurostat data on international immigration flows normally include migrations of both national citizens and foreigners, ideally for a period of at least 12 months. The guidelines for collecting such statistics come from UN Recommendations (United Nations, 1998) and, recently, from an EU regulation pertaining to statistics on migration and international protection, which introduced compulsory data collection in the European Economic Area (European Commission, 2007). Such data should include refugees and asylum seekers who were granted authorization to stay, but data on irregular migration generally cannot be covered.

At the time of this analysis (early 2012), detailed data on migration were only available in international databases up to the end of 2009. Monthly data are published in very few EU Member States, and, due to their rapid and preliminary character, do not always correspond to the annual figures that are published later. 
In addition, the available statistics should be used with caution because the sources of these data are usually administrative databases that are designed for purposes other than statistics. Administrative data sources often exclude some groups of migrants or fail to record some events even if all the relevant groups are included. When analyzing time series, all breaks due to various reasons should be tracked very carefully. These reasons may be categorised into two groups: (i) changes in administrative or legal measures, such as changes in the registration and regularisation of illegal migrants, or (ii) changes in the statistical methodology, e.g. using new data sources, definitions, etc. These artificial changes or breaks in series can easily appear to be changes in migration trends (Herm and Poulain, 2010) and distort the analysis of the impact of the economic crisis.

Several EU Member States changed their data collection methodology in order to respect the harmonised definitions stipulated by the recently adopted EU Regulation on Migration Statistics. While such changes in definitions were expected to be reflected in the 2008 data and will be compulsory for 2009 , some Member States had already altered their methodology in order to implement the Regulation gradually over several years. Therefore, unfortunately, breaks in time series can be found in recent years at the same time that the economic crisis occurred.

In order to identify the possible impact of the economic crisis on international migration flows, the ratio between successive years of annual total numbers of immigrants and emigrants has been calculated. Annual aggregated data do not give enough information to identify the impact of external factors, or the precise timing of when rapid changes occur. Monthly data are preferable, but such data are not included in the Eurostat data collection program. Monthly data for the years 2007-2009 are only available for eight EU countries: Austria, the Czech Republic, Denmark, Latvia, the Netherlands, Slovakia, Spain and Sweden; the data have been adjusted to suppress seasonal variations.

Also assuming that the so-called 'old EU 15' might exhibit a pattern different from the 'new EU 12 ' concerning recent changes in the flows linked to the economic crisis, these two groups of countries have also been distinguished if data were available.

The impact of the crisis could vary for various groups of migrants depending on citizenship. It was therefore thought prudent to split the data by EU and non-EU citizens. In addition to international migration data, the Eurostat database also proposes the collection of data on residence permits and asylum, which could be used for assessing the impact of the economic crisis on international immigration flows of non-EU citizens. Annual data on residence permits were first collected in 2008 and can be compared with similar data from 2009 even if some improvements in data collection have been introduced.

It appeared that several member states did not have data for every year of the relevant period while other data were clearly not comparable between successive years. For these countries, (Belgium, the Czech Republic, Bulgaria, France, Greece, Romania and Spain), the data were estimated in order to be able to present global trends for the EU 27, EU 15 and EU 12. 
It is important to mention that the figures in some countries' international and national databases do not correspond to each other. For some countries (Austria, Denmark, Germany, the Netherlands and Poland) that changed their methodology in 2008 in response to the EU Regulation, a methodological break appears in the Eurostat database, but an unbroken time series can be found at the national level. In these situations, the national data have been used for the analysis to ensure the validity of the apparent trends.

\section{Results}

The following analysis examines the impact of the recent economic crisis on international migration flows to and from the EU Member States, first, by considering annual total migration data (including both nationals and non-nationals), second, by examining monthly data for the few countries where such data are available, and third, by comparing international migration trends separately for nationals, citizens of other EU countries and non-EU citizens. As already mentioned, we will use the unemployment rate adjusted to suppress seasonal variations to measure the intensity of the economic crisis and its impact on international migration.

\section{Analysing the Annual Data}

For the EU as a whole, the annual figures and estimates for the years 2004-2009 show a sharp increase in 2007 followed by a decrease in total immigration for 2008 and 2009 (-5\% between 2007 and 2008 and $-9 \%$ between 2008 and 2009). We found that the 2009 level is close to the average for the years 2004-2006. Conversely, total emigration increases from 2007 to 2008 (+15\%), and remains at the 2008 level for 2009 (Figure 1).

Considering the "old" EU 15 and the "new" EU 12 countries separately, the relative evolution of total immigration and emigration in these two groups of countries is compared using 2004 as a reference year (2004 $=100 \%$ ) (Figure 2). Compared to the EU 27 totals, the trends for these two groups of countries show some differences. The EU 12 group presents the largest increase in immigration between 2004 and 2007 (47\%) while the EU 15 shows a smaller increase of only $12 \%$. The large increase for the EU 12 is somewhat hidden by changes in the totals for the EU 27 from 2004 to 2007, due to smaller absolute figures for the EU 12. In 2008, immigration to the EU 12 is still increasing while immigration to the EU 15 has begun to decrease. In 2009 the decrease continues for the EU 15, reducing immigration to the average level for the years 2004 to 2006, while immigration to the EU 12 begins to decrease but still remains larger than the 2004-2006 levels.

The emigration trends are different. In 2008, EU 15 emigration shows an increase of $16 \%$ over 2007 and status quo in 2009, whereas EU 12 emigration increases steadily starting in $\mathbf{2 0 0 5}$ - before the economic crisis. While the total increase from 2004 to 2009 is similar for both groups of countries, the timing of the increase is different. The impact of the crisis on both immigration and emigration is therefore somewhat different for the "old" EU 15 and the "new" EU 12 Member States. 
Figure 1: Total immigration and emigration compared with fluctuations in the average unemployment rate*, EU 27, 2004-2009

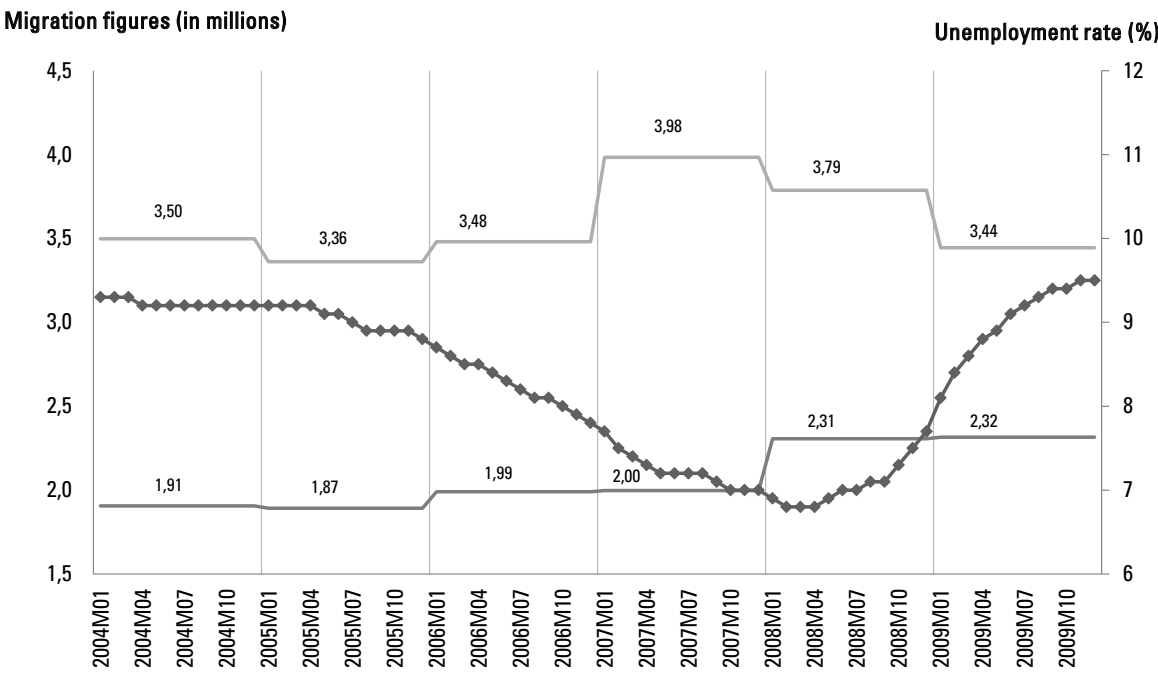

—Immigration (annual total) _Emigration (annual total) $\quad$ —Unemployment rate EU27

* Monthly figures adjusted for seasonal variations.

Source: Authors' calculations based on the Eurostat and ILO Laborsta databases.

Figure 2: Relative immigration and emigration flows for the EU 15 and EU 12, 2004-2009

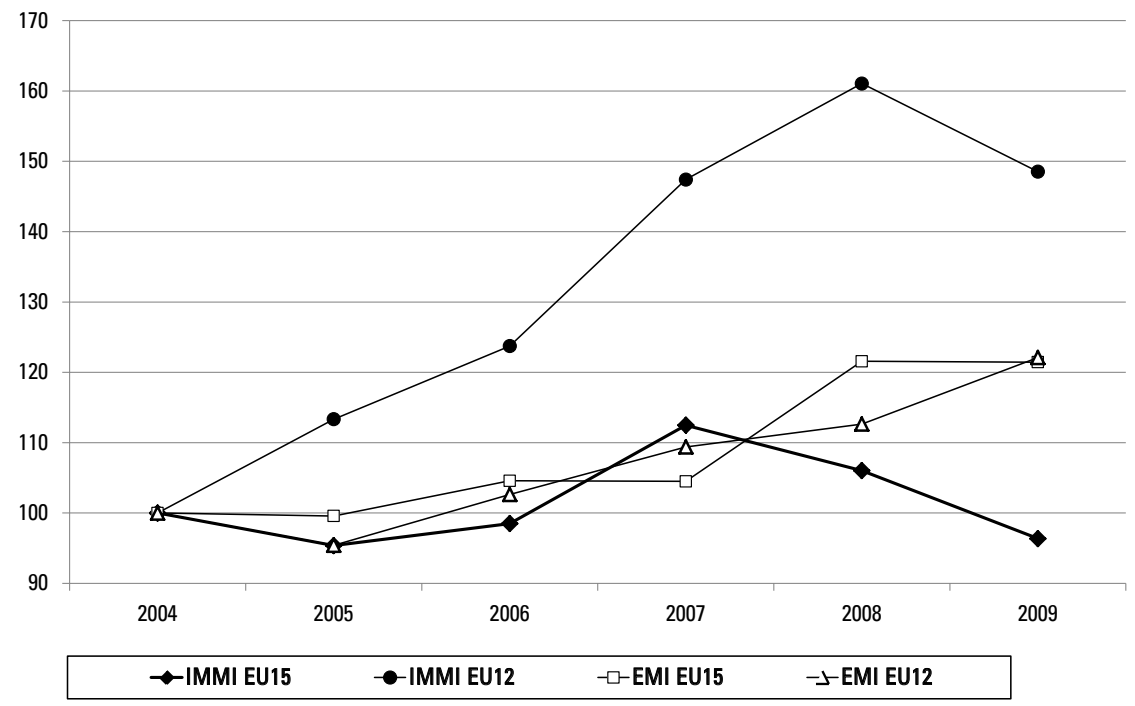

Source: Authors' calculations based on the Eurostat database. 
Table 1: Relative change in annual immigration, emigration and unemployment rates, 2007-2008 and 2008-2009

\begin{tabular}{|c|c|c|c|c|c|c|}
\hline Countries & $\begin{array}{c}\text { Unempl. } \\
2008 / 2007\end{array}$ & $\begin{array}{c}\text { Immigr. } \\
2008 / 2007\end{array}$ & $\begin{array}{c}\text { Emigr. } \\
2008 / 2007\end{array}$ & $\begin{array}{c}\text { Unempl. } \\
\text { 2009/2008 }\end{array}$ & $\begin{array}{c}\text { Immigr. } \\
2009 / 2008\end{array}$ & $\begin{array}{c}\text { Emigr. } \\
2009 / 2008\end{array}$ \\
\hline Austria & $-13.7 \%$ & $3.2 \%$ & $5.2 \%$ & $25.7 \%$ & $-2.1 \%$ & $15.3 \%$ \\
\hline Belgium & $-5.9 \%$ & $12.1 \%$ & $10.1 \%$ & $11.7 \%$ & & \\
\hline Bulgaria & $-18.7 \%$ & $-20.8 \%$ & $-28.6 \%$ & $22.0 \%$ & & \\
\hline Cyprus & $-8.6 \%$ & $-25.9 \%$ & $17.8 \%$ & $45.6 \%$ & $-17.2 \%$ & $-6.4 \%$ \\
\hline Czech Republic & $-17.5 \%$ & & & $51.0 \%$ & & \\
\hline Denmark & $-11.3 \%$ & $12.5 \%$ & $4.6 \%$ & $80.0 \%$ & $-7.7 \%$ & $3.2 \%$ \\
\hline Estonia & $20.5 \%$ & $-1.9 \%$ & $0.5 \%$ & $148.5 \%$ & $5.8 \%$ & $5.5 \%$ \\
\hline Finland & $-6.5 \%$ & $11.9 \%$ & $9.8 \%$ & $28.1 \%$ & $-8.3 \%$ & $-11.0 \%$ \\
\hline France & $-6.2 \%$ & $3.4 \%$ & $3.8 \%$ & $21.1 \%$ & & \\
\hline Germany & $-12.7 \%$ & $1.0 \%$ & $15.9 \%$ & $2.5 \%$ & $5.7 \%$ & $-0.6 \%$ \\
\hline Greece & $-7.5 \%$ & & & $23.8 \%$ & & \\
\hline Hungary & $6.5 \%$ & & & $27.8 \%$ & & \\
\hline Ireland & $39.1 \%$ & $-28.0 \%$ & $41.5 \%$ & $87.3 \%$ & $-41.5 \%$ & $8.4 \%$ \\
\hline Italy & $9.9 \%$ & $-4.2 \%$ & $24.1 \%$ & $14.3 \%$ & $-17.2 \%$ & $-0.4 \%$ \\
\hline Latvia & $23.8 \%$ & $-2.1 \%$ & $43.6 \%$ & $130.2 \%$ & $-22.4 \%$ & $23.0 \%$ \\
\hline Lithuania & $35.3 \%$ & $8.0 \%$ & $22.8 \%$ & $134.6 \%$ & $-30.2 \%$ & $29.1 \%$ \\
\hline Luxembourg & $16.1 \%$ & $6.5 \%$ & $-5.8 \%$ & $10.5 \%$ & $-11.3 \%$ & $-8.8 \%$ \\
\hline Malta & $-6.8 \%$ & $34.2 \%$ & $31.2 \%$ & $16.5 \%$ & $-19.9 \%$ & $12.0 \%$ \\
\hline Netherlands & $-13.4 \%$ & $22.9 \%$ & $-1.3 \%$ & $23.9 \%$ & $3.4 \%$ & $-5.2 \%$ \\
\hline Poland & $-25.7 \%$ & & & $14.4 \%$ & & \\
\hline Portugal & $-4.9 \%$ & $-35.8 \%$ & $-24.0 \%$ & $24.5 \%$ & $8.7 \%$ & $-17.0 \%$ \\
\hline Romania & $-7.7 \%$ & $4.8 \%$ & $-1.0 \%$ & $58.3 \%$ & & \\
\hline Slovakia & $-14.6 \%$ & $9.6 \%$ & $36.1 \%$ & $26.1 \%$ & $-12.2 \%$ & $-2.1 \%$ \\
\hline Slovenia & $-13.0 \%$ & $5.1 \%$ & $-19.0 \%$ & $36.4 \%$ & $-1.3 \%$ & $55.2 \%$ \\
\hline Spain & $37.5 \%$ & $-24.2 \%$ & $17.3 \%$ & $58.6 \%$ & $-31.3 \%$ & $21.5 \%$ \\
\hline Sweden & $1.0 \%$ & $1.7 \%$ & $-0.3 \%$ & $34.8 \%$ & $1.1 \%$ & $-13.4 \%$ \\
\hline $\begin{array}{l}\text { United } \\
\text { Kingdom }\end{array}$ & $6.6 \%$ & $12.1 \%$ & $34.5 \%$ & $34.1 \%$ & $-4.0 \%$ & $13.8 \%$ \\
\hline $\begin{array}{l}\text { Correlation } \\
\text { between } \\
\text { changes in } \\
\text { unemployment } \\
\text { and migration }\end{array}$ & & $\begin{array}{r}-30.2 \% \\
\text { p-value }= \\
0.081\end{array}$ & $\begin{array}{r}45.5 \% \\
\text { p-value }= \\
0.015\end{array}$ & & $\begin{array}{r}-34.7 \% \\
\text { p-value }= \\
0.073\end{array}$ & $\begin{array}{r}36.4 \% \\
\text { p-value }= \\
0.063\end{array}$ \\
\hline
\end{tabular}

Source: Authors' calculations based on the Eurostat and ILO Laborsta databases. 
The impact of the economic crisis on international migration flows can also be analysed for each country individually. The correlation between changes in annual unemployment rates and changes in total immigration and emigration between 2007 and 2008 is calculated for this purpose (Table 1). For individual countries, it appears that changes in immigration are slightly negatively correlated with changes in unemployment rates $(R=-0.302$, $p$-value $=0.081)$, while changes in emigration are positively correlated $(R=0.455, p$-value $=0.015)$; however, only the latter is statistically significant. The same exercise for changes occurring between 2008 and 2009 produces correlation coefficients of -0.347 $(p$-value $=0.073)$ for immigration and $+0.364(p$-value $=0.063)$ for emigration, but neither $\mathrm{p}$-values are significant.

\section{Considering the Monthly Data}

Monthly international migration data for recent years are available for eight EU countries: Austria, the Czech Republic, Denmark, Latvia, the Netherlands, Slovakia, Spain and Sweden ${ }^{6}$; the Austrian data date only from 2008, and there appear to be some reliability problems with the Czech Republic data. Monthly migration figures have been corrected for seasonal variations and compared with seasonallyadjusted unemployment data extracted from the ILO Laborsta database (Figure 3).

Some similarities and differences may be seen between the above-mentioned countries. In the first half of 2008, just prior to the crisis, unemployment was noticeably lower in five of the seven countries as compared to 2007 (except in Spain and Latvia, and no data are available for Austria). In Spain, an economic crisis seemed to be in progress before the international crisis, and unemployment was already increasing before 2008. In the Czech Republic, Denmark and Sweden, unemployment started steadily increasing in the early autumn of 2008 synchronically with the crisis, while in Slovakia and the Netherlands, the unemployment rates increased somewhat later, at the beginning of 2009.

The migration data do not exhibit a clear pattern but some similarities can still be found. Most countries show a decrease in immigration close to the end of 2008, and the lower level persisted in 2009. The point where the largest monthly decreases occurred can be identified more precisely as September and October 2008, except for the Netherlands, where it only took place during the first months of 2009 , and Sweden, where the decrease was minimal.

Rising unemployment also exhibits an impact on emigration, but after some delay. The similarities between the emigration patterns of various countries are quite limited, and in some cases the trends are opposite. While it is expected that emigration would increase with unemployment, emigration in the Netherlands and Sweden did not increase, and the level remained slightly lower than before the crisis. In the other countries, only a very small increase can be seen during the last months of 2008.

Any major increase or decrease in migration that occurs in January of a particular year is more likely the result of a methodological change than a real change in migration flow.

6 Monthly migration data were found from the websites of the corresponding respective National Statistical Offices. 


\section{Comparing Nationals, Other EU Citizens and Non-EU Citizens}

So far we have described total migration flows without distinguishing between nationals of each country, other EU citizens and non-EU citizens. The final analysis is based on citizenship. 2007 and 2008 data were compared for this purpose, following the same methodology that was used to produce the results presented in figure 1 and in the annex.

As shown in table 2, following a strong increase in 2007, immigration decreased in 2008 and 2009 - a decrease that could have been caused by the economic crisis - which brought the level back to that of 2004 and 2005. This decrease is far from uniform among the different groups of migrants. Return migration of nationals increased about $5 \%$ in 2008 and remained at this level in 2009. Immigration decreased, but differentiating between EU citizens and non-EU citizens, shows that in 2008 this decrease was only due to EU citizens; non-EU citizens immigrated in larger numbers in 2008 compared to 2007. In 2009, immigration decreased among both EU and non-EU citizens, and the total decrease negates the increase of the years 2005 and 2006.

All groups experienced an increase in emigration in 2008, but the size of these increases varies from about $5 \%$ for nationals to $30 \%$ for other EU citizens. In 2009, this increase continued only for non-nationals, but was much smaller than that of 2008.

An analysis of the migration data by citizenship for each country shows a highly variable situation among EU countries. Such variability clearly results from the various migration histories experienced by the countries, and from the different socio-economic characteristics of their non-native populations. This distinction between nationals and non-nationals is shown by country in table 3 and the correlation with unemployment is calculated. A negative correlation between unemployment and immigration is found for both groups: for nationals, $R=-0.191$ ( $p$-value $=0.210$ ) and for non-nationals, $R=-0.487$ ( $p$-value $=0.015$ ); only the latter is significant. Conversely, a positive correlation emerges between unemployment and emigration: for nationals, $R=0.370$ ( $p$-value $=$ 0.059 ) and for non-nationals, $R=0.255$ ( $p$-value $=0.146$ ). However, neither of these correlations is statistically significant.

Non-nationals living in an EU country can be categorised into two subgroups: EU citizens who are not nationals of the country to or from which they migrate (other EU citizens) and non-EU citizens. These two groups face different levels of obstacles to migration. Estimates based on available data from the $27 \mathrm{EU}$ countries indicate that in 2008 , as compared to 2007 , the immigration of non-EU citizens (from both outside and inside the EU) increased by $6 \%$, while for other EU citizens, most of whom enjoy free movement within the EU, there was a decrease of $19 \%$ (Table 2). Both groups show an increase in emigration that is larger for other EU citizens $(+30 \%)$ than for non-EU citizens $(+13 \%)$. There is a non-significant positive correlation between changes in the immigration of EU citizens and non-EU citizens $(R=0.278)$ in a given country; a correlation does not appear to exist in the changes in emigration between the two groups $(R=0.146)$ (Table 4). 
Figure 3: Monthly changes in unemployment and international migration, selected countries, 2007-2009

\section{Austria}

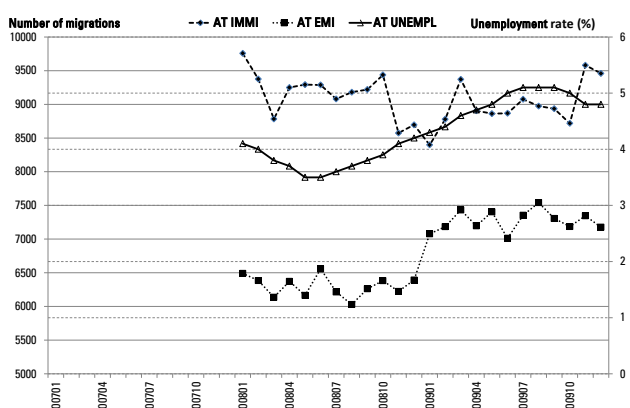

\section{Latvia}

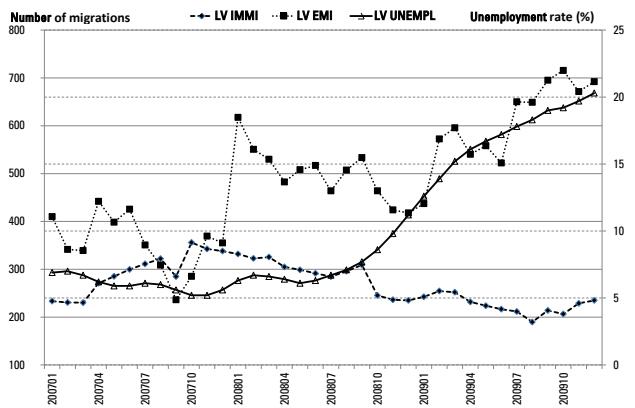

\section{Spain}

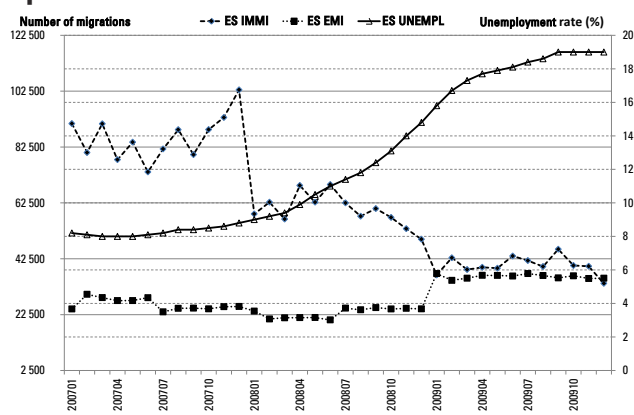

\section{Sweden}

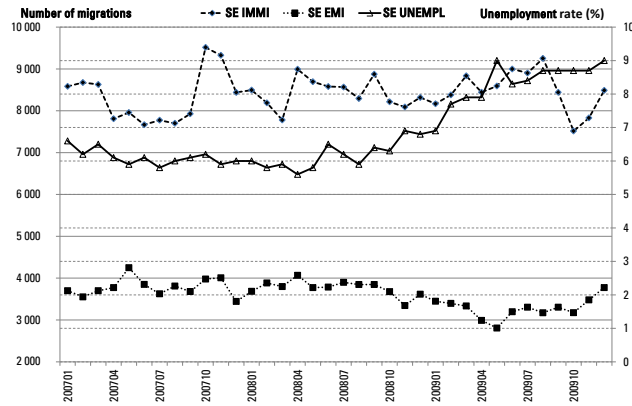

\section{Denmark}

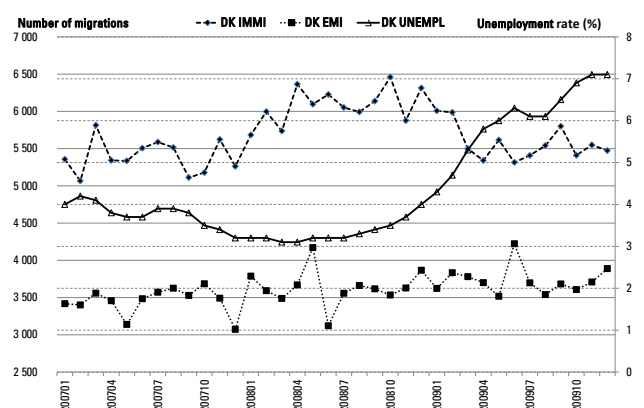

\section{The Netherlands}

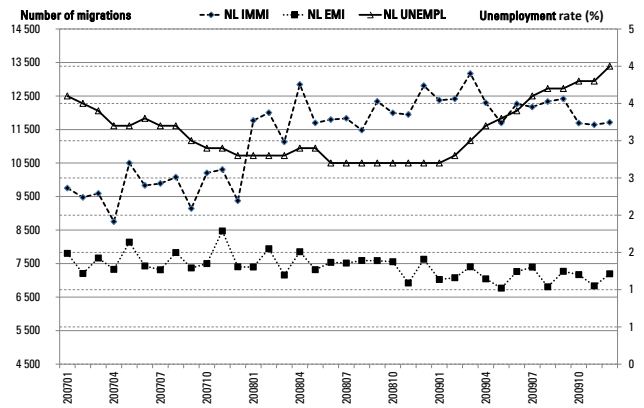

\section{Slovakia}

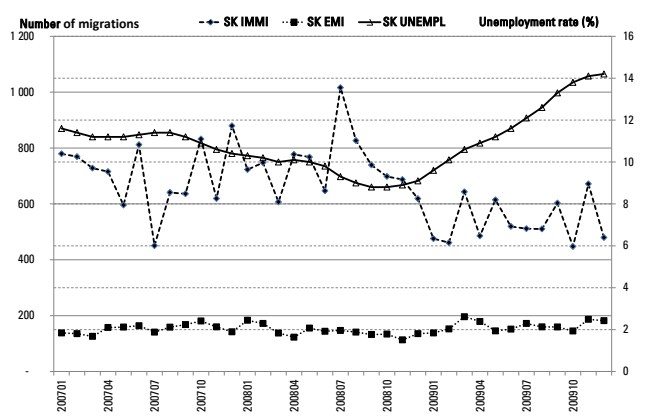

\section{The Czech Republic}

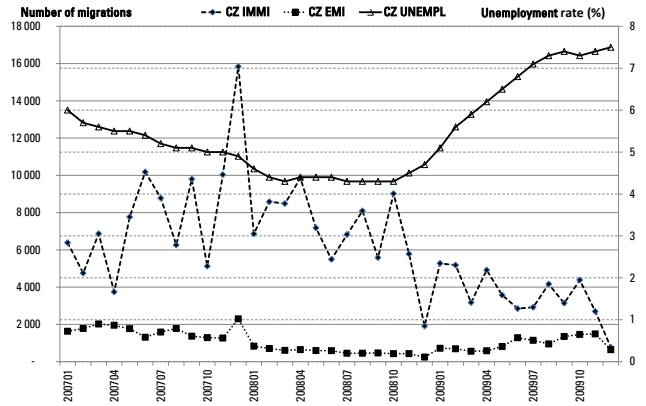

Source: Authors' calculations based on national databases and the ILO Laborsta database. 
Table 2: Estimated total immigration and emigration in the 27 EU Member States* by citizenship groups, 2004-2009

\begin{tabular}{|c|c|c|c|c|c|c|}
\hline Immigration & 2004 & 2005 & 2006 & 2007 & 2008 & 2009 \\
\hline TOTAL & 3,497 & 3,361 & 3,481 & 3,984 & 3,787 & 3,445 \\
\hline \multicolumn{7}{|l|}{ comprised of } \\
\hline Nationals & 621 & 561 & 535 & 538 & 568 & 568 \\
\hline Non-Nationals & 2,876 & 2,800 & 2,946 & 3,446 & 3,219 & 2,877 \\
\hline \multicolumn{7}{|l|}{ comprised of } \\
\hline EU citizens & 1,195 & 1,232 & 1,296 & 1,720 & 1,379 & 1,206 \\
\hline non-EU citizens & 1,681 & 1,568 & 1,650 & 1,726 & 1,840 & 1,671 \\
\hline Emigration & 2004 & 2005 & 2006 & 2007 & 2008 & 2009 \\
\hline TOTAL & 1,906 & 1,893 & 1,991 & 1,997 & 2,306 & 2,315 \\
\hline \multicolumn{7}{|l|}{ comprised of } \\
\hline Nationals & 661 & 663 & 724 & 702 & 741 & 703 \\
\hline Non-Nationals & 1,245 & 1,230 & 1,266 & 1,295 & 1,565 & 1,612 \\
\hline \multicolumn{7}{|l|}{ comprised of } \\
\hline EU citizens & 547 & 513 & 554 & 583 & 742 & 769 \\
\hline non-EU citizens & 699 & 717 & 712 & 712 & 823 & 843 \\
\hline
\end{tabular}

* For comparative purposes the data include the 27 EU Member States from 2004 although Bulgaria and Romania joined the EU in 2007.

Source: Eurostat database and authors' estimates. 
Table 3: Relative change in annual immigration, emigration and unemployment rates of nationals and non-nationals, 2007-2008

\begin{tabular}{|c|c|c|c|c|c|}
\hline Countries & $\begin{array}{c}\text { Total } \\
\text { unempl. }\end{array}$ & $\begin{array}{l}\text { Immigr. of } \\
\text { nationals }\end{array}$ & $\begin{array}{c}\text { Immigr. of } \\
\text { non-nationals }\end{array}$ & $\begin{array}{l}\text { Emigr. of } \\
\text { nationals }\end{array}$ & $\begin{array}{c}\text { Emigr. of } \\
\text { non-nationals }\end{array}$ \\
\hline Austria & $-13.7 \%$ & $2.7 \%$ & $2.9 \%$ & $5.0 \%$ & $4.9 \%$ \\
\hline Belgium & $-5.9 \%$ & & & & \\
\hline Bulgaria & $-18.7 \%$ & $-23.4 \%$ & $45.0 \%$ & $-27.8 \%$ & $-91.4 \%$ \\
\hline Cyprus & $-8.6 \%$ & $15.5 \%$ & $-28.1 \%$ & $-52.6 \%$ & $-13.2 \%$ \\
\hline Czech Republic & $-17.5 \%$ & & & & \\
\hline Denmark & $-11.3 \%$ & $2.4 \%$ & $17.8 \%$ & $-7.7 \%$ & $27.1 \%$ \\
\hline Estonia & $20.5 \%$ & $-2.6 \%$ & $-1.2 \%$ & $-2.0 \%$ & $22.3 \%$ \\
\hline Finland & $-6.5 \%$ & $8.0 \%$ & $12.5 \%$ & $-1.8 \%$ & $43.9 \%$ \\
\hline France & $-6.2 \%$ & $0.4 \%$ & $4.9 \%$ & & \\
\hline Germany & $-12.7 \%$ & $2.2 \%$ & $-0.4 \%$ & $8.5 \%$ & $17.9 \%$ \\
\hline Greece & $-7.5 \%$ & & & & \\
\hline Hungary & $6.5 \%$ & & & & \\
\hline Ireland & $39.1 \%$ & $4.2 \%$ & $-36.3 \%$ & $2.3 \%$ & $13.0 \%$ \\
\hline Italy & $9.9 \%$ & $-10.9 \%$ & $-3.6 \%$ & $20.1 \%$ & $33.0 \%$ \\
\hline Latvia & $23.8 \%$ & $-4.8 \%$ & $-1.1 \%$ & $89.2 \%$ & $6.4 \%$ \\
\hline Lithuania & $35.3 \%$ & $3.2 \%$ & $19.9 \%$ & $17.1 \%$ & $49.8 \%$ \\
\hline Luxembourg & $16.1 \%$ & $5.3 \%$ & $6.1 \%$ & $3.3 \%$ & $-8.1 \%$ \\
\hline Malta & $-6.8 \%$ & $0.6 \%$ & $41.1 \%$ & $6.4 \%$ & $40.2 \%$ \\
\hline Netherlands & $-13.4 \%$ & $9.8 \%$ & $17.5 \%$ & $-4.6 \%$ & $4.4 \%$ \\
\hline Poland & $-25.7 \%$ & & & & \\
\hline Portugal & $-4.9 \%$ & & & & \\
\hline Romania & $-7.7 \%$ & & & & \\
\hline Slovakia & $-14.6 \%$ & $-4.7 \%$ & $10.9 \%$ & $-1.7 \%$ & $65.6 \%$ \\
\hline Slovenia & $-13.0 \%$ & $55.8 \%$ & $1.7 \%$ & $50.0 \%$ & $-37.8 \%$ \\
\hline Spain & $37.5 \%$ & $-10.5 \%$ & $-24.8 \%$ & $22.6 \%$ & $16.6 \%$ \\
\hline Sweden & $1.0 \%$ & $11.9 \%$ & $-0.7 \%$ & $4.2 \%$ & $-6.6 \%$ \\
\hline $\begin{array}{l}\text { United } \\
\text { Kingdom }\end{array}$ & $6.6 \%$ & $19.1 \%$ & $11.0 \%$ & $4.1 \%$ & $69.2 \%$ \\
\hline $\begin{array}{l}\text { Correlation } \\
\text { between } \\
\text { unemployment } \\
\text { and migration }\end{array}$ & & $\begin{array}{r}-19.1 \% \\
\text { p-value }= \\
0.210\end{array}$ & $\begin{array}{r}-48.7 \% \\
\text { p-value }= \\
0.015\end{array}$ & $\begin{array}{r}37.0 \% \\
\text { p-value }= \\
0.059\end{array}$ & $\begin{array}{r}25.5 \% \\
\text { p-value }= \\
0.146\end{array}$ \\
\hline
\end{tabular}

Source: Authors' calculations based on the Eurostat and ILO Laborsta databases. 
Table 4: Relative change in immigration and emigration of other EU citizens and non-EU citizens, 2007-2008

\begin{tabular}{|c|c|c|c|c|}
\hline Countries & $\begin{array}{c}\text { Immigr. of other } \\
\text { EU citizens }\end{array}$ & $\begin{array}{c}\text { Immigr. of } \\
\text { non-EU citizens }\end{array}$ & $\begin{array}{l}\text { Emigr. of other } \\
\text { EU citizens }\end{array}$ & $\begin{array}{c}\text { Emigr. of } \\
\text { non-EU citizens }\end{array}$ \\
\hline Austria & $5.9 \%$ & $-1.1 \%$ & $12.4 \%$ & $-2.7 \%$ \\
\hline \multicolumn{5}{|l|}{ Belgium } \\
\hline \multicolumn{5}{|l|}{ Bulgaria } \\
\hline Cyprus & $-25.3 \%$ & $-64.3 \%$ & $-15.2 \%$ & $-12.8 \%$ \\
\hline \multicolumn{5}{|l|}{ Czech Republic } \\
\hline Denmark & $-6.6 \%$ & $-17.5 \%$ & $27.9 \%$ & $26.3 \%$ \\
\hline Estonia & $-9.0 \%$ & $8.7 \%$ & $126.8 \%$ & $-17.8 \%$ \\
\hline Finland & $8.0 \%$ & $15.3 \%$ & $24.1 \%$ & $73.5 \%$ \\
\hline \multicolumn{5}{|l|}{ France } \\
\hline Germany & $-2.3 \%$ & $2.4 \%$ & $17.2 \%$ & $18.8 \%$ \\
\hline \multicolumn{5}{|l|}{ Greece } \\
\hline \multicolumn{5}{|l|}{ Hungary } \\
\hline Ireland & $-38.5 \%$ & $-30.3 \%$ & $7.6 \%$ & $18.2 \%$ \\
\hline Italy & $-34.5 \%$ & $49.0 \%$ & $62.2 \%$ & $7.6 \%$ \\
\hline Latvia & $-3.0 \%$ & $2.2 \%$ & $32.1 \%$ & $4.4 \%$ \\
\hline Lithuania & $19.4 \%$ & $20.0 \%$ & $2.3 \%$ & $61.3 \%$ \\
\hline Luxembourg & $8.1 \%$ & $-2.9 \%$ & $-10.6 \%$ & $9.0 \%$ \\
\hline Malta & $19.4 \%$ & $86.8 \%$ & $39.2 \%$ & $45.8 \%$ \\
\hline Netherlands & $28.2 \%$ & $5.1 \%$ & $15.1 \%$ & $-7.2 \%$ \\
\hline \multicolumn{5}{|l|}{ Poland } \\
\hline \multicolumn{5}{|l|}{ Portugal } \\
\hline \multicolumn{5}{|l|}{ Romania } \\
\hline Slovakia & $-7.2 \%$ & $40.3 \%$ & $24.4 \%$ & $103.5 \%$ \\
\hline Slovenia & $-21.8 \%$ & $4.2 \%$ & $-33.4 \%$ & $-38.4 \%$ \\
\hline Spain & $-50.3 \%$ & $-6.1 \%$ & $54.3 \%$ & $11.6 \%$ \\
\hline Sweden & $-3.1 \%$ & $0.8 \%$ & $2.8 \%$ & $-16.8 \%$ \\
\hline $\begin{array}{l}\text { United } \\
\text { Kingdom }\end{array}$ & $15.0 \%$ & $8.5 \%$ & $93.8 \%$ & $52.1 \%$ \\
\hline $\begin{array}{l}\text { Correlation } \\
\text { between } \\
\text { change for EU } \\
\text { and non-EU } \\
\text { citizens }\end{array}$ & & $\begin{array}{r}27.8 \% \\
p \text {-value }=0.132\end{array}$ & & $\begin{array}{r}14.6 \% \\
p \text {-value }=0.282\end{array}$ \\
\hline
\end{tabular}

Source: Authors' calculations based on the Eurostat and ILO Laborsta databases. 
Table 5: Number of asylum applications and first residence permits, 2008-2009

\begin{tabular}{|c|c|c|c|c|c|c|c|}
\hline \multirow[b]{2}{*}{ Country } & \multirow[b]{2}{*}{ 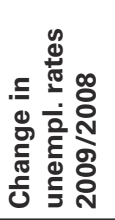 } & \multicolumn{3}{|c|}{ Asylum applications } & \multicolumn{3}{|c|}{ Residence permits } \\
\hline & & œ̊ㅇㅇ & 용 & 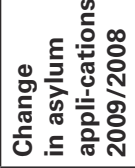 & 串 & 옹 & 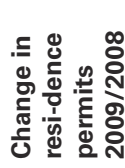 \\
\hline Austria & $25.7 \%$ & 12,750 & 15,815 & $24.0 \%$ & 21,783 & 28,035 & $28.7 \%$ \\
\hline Belgium & $11.7 \%$ & 11,395 & 17,215 & $51.1 \%$ & 46,201 & 58,939 & $27.6 \%$ \\
\hline Bulgaria & $22.0 \%$ & 745 & 855 & $14.8 \%$ & 3,933 & 4,385 & $11.5 \%$ \\
\hline Cyprus & $45.6 \%$ & 3,920 & 3,200 & $-18.4 \%$ & 25,156 & 25,638 & $1.9 \%$ \\
\hline Czech Republic & $51.0 \%$ & 1,650 & 1,245 & $-24.5 \%$ & 61,350 & 27,539 & $-55.1 \%$ \\
\hline Denmark & $80.0 \%$ & 2,375 & 3,775 & $58.9 \%$ & 31,655 & 26,409 & $-16.6 \%$ \\
\hline Estonia & $148.5 \%$ & 15 & 35 & $133.3 \%$ & 3,884 & 3,777 & $-2.8 \%$ \\
\hline Finland & $28.1 \%$ & 3,770 & 5,700 & $51.2 \%$ & 21,873 & 18,034 & $-17.6 \%$ \\
\hline France & $21.1 \%$ & 41,845 & 42,070 & $0.5 \%$ & 188,723 & 193,500 & $2.5 \%$ \\
\hline Germany & $2.5 \%$ & 21,365 & 27,650 & $29.4 \%$ & 114,289 & 121,954 & $6.7 \%$ \\
\hline Greece & $23.8 \%$ & 19,885 & 15,925 & $-19.9 \%$ & 40,411 & 45,148 & $11.7 \%$ \\
\hline Hungary & $27.8 \%$ & 3,175 & 4,670 & $47.1 \%$ & 37,486 & 14,289 & $-61.9 \%$ \\
\hline Ireland & $87.3 \%$ & 3,805 & 2,660 & $-30.1 \%$ & 28,926 & 25,509 & $-11.8 \%$ \\
\hline Italy & $14.3 \%$ & 30,145 & 17,670 & $-41.4 \%$ & 550,226 & 506,833 & $-7.9 \%$ \\
\hline Latvia & $130.2 \%$ & 50 & 50 & $0.0 \%$ & 7,706 & 2,304 & $-70.1 \%$ \\
\hline Lithuania & $134.6 \%$ & 520 & 450 & $-13.5 \%$ & 5,298 & 2,659 & $-49.8 \%$ \\
\hline Luxembourg & $10.5 \%$ & 455 & 485 & $6.6 \%$ & & & \\
\hline Malta & $16.5 \%$ & 2,605 & 2,385 & $-8.4 \%$ & 4,989 & 3,682 & $-26.2 \%$ \\
\hline Netherlands & $23.9 \%$ & 13,380 & 14,880 & $11.2 \%$ & 62,589 & 56,489 & $-9.7 \%$ \\
\hline Poland & $14.4 \%$ & 7,200 & 9,655 & $34.1 \%$ & 40,907 & 33,427 & $-18.3 \%$ \\
\hline Portugal & $24.5 \%$ & 160 & 140 & $-12.5 \%$ & 63,715 & 46,324 & $-27.3 \%$ \\
\hline Romania & $58.3 \%$ & 1,180 & 965 & $-18.2 \%$ & 19,354 & 15,380 & $-20.5 \%$ \\
\hline Slovakia & $26.1 \%$ & 905 & 820 & $-9.4 \%$ & 8,025 & 5,336 & $-33.5 \%$ \\
\hline Slovenia & $36.4 \%$ & 240 & 185 & $-22.9 \%$ & 2,9215 & 15,759 & $-46.1 \%$ \\
\hline Spain & $58.6 \%$ & 4,515 & 3,005 & $-33.4 \%$ & 399,827 & 290,813 & $-27.3 \%$ \\
\hline Sweden & $34.8 \%$ & 24,365 & 23,680 & $-2.8 \%$ & 84,144 & 91,337 & $8.5 \%$ \\
\hline $\begin{array}{l}\text { United } \\
\text { Kingdom }\end{array}$ & $34.1 \%$ & 31,315 & 30,675 & $-2.0 \%$ & 633,240 & 671,344 & $6.0 \%$ \\
\hline Total EU 27 & & 243,730 & 245,860 & & $2,534,905$ & $2,334,843$ & \\
\hline $\begin{array}{l}\text { Correlation } \\
\text { with change in } \\
\text { unemployment }\end{array}$ & & & & $\begin{array}{r}0.218 \\
(p-\text { value } \\
=0.052)\end{array}$ & & & $\begin{array}{r}-0.399 \\
(p-v a l u e \\
=0.033 \text { ) }\end{array}$ \\
\hline
\end{tabular}

Source: Eurostat, UNHCR and ILO databases and authors' calculations. 
For non-EU citizens, data on the annual numbers of residence permits and asylum requests might provide additional information. Asylum data harmonised at the EU level are available for the whole period studied, but data on residence permits has only existed in the Eurostat database as of 2008 (Table 5). These data show that increases in the number of residence permits are negatively correlated with increases in unemployment rates $(R=-0.399$ and $p$-value $=0.033$ ) while the opposite is true for asylum $(R=0.218$ and $p$-value $=0.052)$, but the correlation is not statistically significant.

\section{Discussion}

It is important to bear in mind the general weakness of international migration data. Administrative databases are the main sources of international migration statistics and these data sources are typified by problems of under-reporting and poor reliability, mostly due to unreported emigration. Any investigation of international migration data must inevitably begin with an assessment of the reliability and comparability of each country's data before attempting to identify the main features of international migration patterns and trends. Significant improvements in the quality of the data have been made in accordance with a recently adopted EU Regulation (European Commission, 2007). However, these improvements sometimes involve changes in definitions and data collection methods, causing breaks in the time series. For example, Germany revised its immigration figures for 2009 from 721,014 according to the national definition, to 346,216 in conformity with the EU-mandated definition. Therefore, every finding from an analysis of migration data time series should be assessed from the point of view of possible aberrations caused by problems with the data. In-depth investigation of changes in each country's methodology of data collection can help to reveal the impact of the change and to identify the actual effect of the economic crisis on international migration flows. In light of these data problems, this study should be seen as an attempt to reconstruct consistent trends in international migration data at the EU level and to distinguish patterns for different groups based on citizenship. It cannot be considered as the final statement, as data in international databases are often updated or revised.

Let us consider the different components of international migration flows and identify the changes that were concurrent to the economic crisis in order to confirm or refute the statements in the scientific literature.

\section{International Immigration of Non-nationals}

Our study confirmed the impact of the recent economic crisis on international migration flows to EU Member States, which resulted in decreased immigration from 2007 to 2009, as reported by the OECD (2009), Castles (2009), and Castles and Miller (2010). We also verified that the decrease has been greater for EU citizens than for non-EU citizens, i.e. for free-movement as opposed to regulated immigration (Lemaître, 2009). In addition, we found that the decrease for EU citizens was more rapid (beginning in 2008) than for non-EU citizens (beginning in 2009). The number of new residence permits also decreased in 2009 compared to 2008 , and figures for 2010 show a continuing decline. 


\section{International Immigration or Return Migration of Nationals}

We observed an increase in the return migration of nationals, a trend mentioned by Castles (2009). Nevertheless, this was a limited increase that compensated for decreases in 2006 and 2007, during which period lower levels of return migration for nationals reflected higher levels of employment in the EU.

\section{International Emigration or Return Migration of Non-nationals}

An increase in total international emigration from EU countries was observed in 2008 and 2009, compared to earlier years. For EU citizens with the right of free movement, the increase peaked at $30 \%$ in 2008, after which a reduced increase was still evident in 2009. For non-EU citizens, an increase was also registered in 2008 and 2009 but did not exceed $20 \%$. These trends do not corroborate the predictions of Ratha (2009) and Castles and Miller (2010) who forecasted little return migration for non-nationals during the economic crisis.

\section{International Emigration of Nationals}

The emigration of nationals does not exhibit any significant trend and no impact arising from the economic crisis can be observed.

\section{Irregular Migration}

This type of migration is by definition difficult to capture in official statistics and very little is known about it. We found some indications of trends in irregular migration by examining initial applications for asylum. A small increase occurred in 2008 and 2009 but a decrease was registered for 2010. Some researchers (Castles, 2009; Castles and Miller, 2010) foresaw that such a decrease could be linked to the adoption of stricter rules for asylum.

Studying the "old" EU 15 and "new" EU 12 Member States separately, we find that immigration decreased more quickly in the EU 15 than in the EU 12. The decrease in immigration in 2008 and 2009 is estimated to be close to $15 \%$ for the EU 15. For the EU 12, the decrease began in 2009 and is only $8 \%$ less than in 2008. The EU 15 experienced an increase in emigration in 2008 relative to 2007 , but this increase had already stopped by 2009. For the EU 12, emigration increased continuously from 2005 but became more pronounced in 2009. We observed similar trends for the EU 15 and EU 12, but the impact of the crisis seems to be less severe on the EU 12 than on the EU 15.

In order to assess the impact of increasing unemployment on the free movement of EU citizens, it would be worthwhile to compare the migration flows of nationals and other EU citizens separately for the EU 12 and EU 15. However, data on nationals and other EU citizens by country of previous residence would be needed for the EU 12 and EU 15 for such an assessment. Unfortunately, no data cross-tabulating international migration by origin or destination (inside or outside the EU) that distinguishes EU from non-EU citizens is currently available. Therefore, we were not able to verify if "intra-EU immigration, primarily originating from the 'new'EU12 Member States and flowing towards the 'old'EU15 ones that has made up a large proportion of immigrant inflow in certain EU countries were more responsive to the economic cycle," as stated by Papademetriou et 
al. (2009). Nevertheless, considering that free movement mostly applies to EU citizens including nationals while regulated migration pertains only to non-EU citizens, the annual data by citizenship might help to explain the situation. There was a large increase in the number of EU citizens emigrating from their home country (emigration of nationals) and immigrating to another EU Member State (immigration of EU citizens) under favourable economic conditions in the precrisis period, and a comparable decrease during the economic crisis. The number of EU citizens returning to their home countries (emigration of EU citizens and immigration of nationals) shows an increase only in 2008 and 2009 during the economic crisis. Non-EU citizens followed the same trends but the magnitude of the changes was smaller and the response to economic cycles is less evident or less immediate, as it occurred after some delay.

Because the crisis started in mid-2008, the annual figures for 2008 are composite and the annual data could be misleading. Therefore, the impact of the crisis on migration flows could be better assessed using monthly figures. An analysis of the monthly data for the few countries producing such data confirms the synchronism between the change in unemployment rates and immigration. Most of the EU 27 experienced a monthly increase in unemployment rates when the crisis started. Migration in response to that increase seems to have been relatively immediate, at least for EU citizens. Based on annual data, decreased immigration and increased emigration confirm our finding.

As mentioned by several authors (Awad, 2009; United Nations, 2010), an examination of the data for individual countries reveals a large variation in the timing and intensity of the relationship between economics and migration. Historical country-specific factors could affect immigration calculus and the likelihood that flows would respond to economics (OECD, 2009). Our analysis shows that the impact of the recent economic crisis varies greatly from one country to another, and that this can be attributed to the heterogeneity of the economic structure, and to the level of economic development of the EU countries. The historical migration patterns of each country may also magnify or reduce the impact of economic factors. Nevertheless, a positive correlation exists between the changes in unemployment and migration flows for each country, and these findings do not exclude the possibility that immigration decreased and emigration increased due to the economic crisis.

Global data do not clearly show the impact of the changing economic situation on international migration, partly because citizenship groups may act differently. When comparing changes in the migration of the two groups of nonnationals, EU citizens (excluding nationals) and non-EU citizens, we found no significant correlation at the country level for either immigration or emigration. This supports the suggestion that the crisis would have a different impact on regulated migration for $\mathrm{EU}$ and non-EU citizens.

In conclusion, the changes in international migration appeared to occur synchronically with the increase of unemployment precipitated by the recent economic crisis. That the economic crisis had an impact that resulted in a decrease in total immigration and an increase in emigration can thus be confirmed. 
A further research question emerges: whether the increase in immigration to both the EU 12 and EU 15 in 2006 and 2007, before the emergence of the crisis, was exceptional and possibly linked to the pre-crisis overheated economic situation. If so, the decrease that occurred during the crisis could be seen as a return to the previous "normal" and more stable level of immigration. From this viewpoint, the impact of the economic crisis on immigration could be seen as a "cooling down" period after the major economic boom that preceded the crisis. Nevertheless, this hypothesis does not apply to emigration, which was relatively stable from 2004 to 2007 and increased during the economic crisis. Finally, the most relevant finding of the study, in our opinion, is that the global impact of the recent crisis cannot be thoroughly evaluated at this time, as sufficiently detailed and reliable data are not yet available and the post-crisis situation is still unknown.

\section{References}

Awad Ibrahim (2009) The global economic crisis and migrant workers: impact and response, International Migration Program, Geneva, ILO, 60 p.

Beets Gijs and Willekens Frans (2009) The global economic crisis and international migration: an uncertain outlook, Vienna Yearbook of Population Research, special issue on the impact of migration on demographic change and composition in Europe, pp. 19-37.

Castles Stephen (2009) Migration and the global financial crisis: a virtual symposium. Update 1.A: an overview, [online] consulted 01/02/2012. URL: http:// www.age-of-migration.com/uk/financialcrisis/updates/1a.pdf

Castles Stephen and Miller Mark (2010) Migration and the global economic crisis: one year on: a virtual symposium, update 1.L, [online] consulted 01/02/2012. URL: http://www.age-of-migration.com/uk/financialcrisis/updates/ migration_crisis_april2010.pdf

Castles Stephen and Miller Mark (2009) The age of migration. International population movements in the modern world, 4th edition, New York, Guilford Press, $307 \mathrm{p}$.

Coleman David (2008) The demographic effects of international migration in Europe, Oxford Review of Economic Policy, 24 (3), pp. 452-476.

De Beer Joop, Raymer James, Van der Erf Rob and Van Wissen Leo (2010) Overcoming the problems of inconsistent international migration data: a new method applied to flows in Europe, European Journal of Population, 26 (4), pp. $459-481$.

Dobson Janet, Latham Alan and Salt John (2009) On the move? Labour migration in times of recession, Policy Network, [online] consulted 10/01/2012. URL: http://www.policy-network.net/publications_detail.aspx?ID=3194

European Commission (2007) European Parliament and the Council of European Union Regulation (EC) No 862/2007 of the European Parliament and of the Council of 11 July 2007 on Community Statistics on Migration and International Protection and Repealing Council Regulation (EEC) No 311/76 on the Compilation of Statistics on Foreign Workers, Official Journal, L 199. 
Eurostat (2012) Online database, [online] consulted 15/01/2012. URL: http://epp. eurostat.ec.europa.eu/portal/page/portal/population/data/database

Fix Michael, Papademetriou Demetrios, Batalova Jeanne, Terrazas Aaron, Serena Yi-Ying Lin and Mittelstadt Michelle (2009) Migration and global recession, Washington, Migration Policy Institute, $127 \mathrm{p}$.

Frontex (2009) The impact of the global economic crisis on illegal migration to the EU, Warsaw, Risk Analysis Unit, 29 p.

GMG (Global Migration Group) (2009) Fact-sheet on the impact of the economic crisis on immigration policies, [online] consulted 15/01/2012. URL: http:// www.globalmigrationgroup.org/uploads/documents/ILO_FactSheet_1_final_rev_ May_2010.pdf

Herm Anne and Poulain Michel (2010) International migration data as input for population projections, Work session on demographic projections, Eurostat, pp. 255-268.

International Institute for Labour Studies (IILS) (2009) The financial and economic crisis: a decent work response, ILO, 105 p.

ILO (2010) LABORSTA database, [online] consulted 15/01/2012. URL: http:// laborsta.ilo.org

OECD (2010a) International Migration Outlook 2010, OECD Publishing, 358 p.

OECD (2010b) Interview with Georges Lemaitre, OECD international migration expert, on recent migration trends in the European Union, [online] consulted 10/01/2012. URL: http://www.oecd.org/document/6/0,374 6,en_2649_33931_44638406_1_1_1_1,00.html

OECD (2009) International migration and the financial crisis: understanding the links and shaping policy responses, [online] consulted 10/01/2012. URL: http:// www.oecd.org/dataoecd/45/18/46292981.pdf

Martin Philip (2009a) Recession and migration: a new era for labor migration? International Migration Review, 43 (3), pp. 671-691.

Martin Philip (2009b) The recession and migration; alternative scenarios, International Migration Institute, WP 13-2009, University of Oxford, 16 p.

Papademetriou Demetrios, Sumption Madeleine and Somerville Will (2009) Migration and the economic downturn: what to expect in the EU?, Migration Policy Institute, Washington, $15 \mathrm{p}$.

Poulain Michel, Perrin Nicolas and A. Singelton Ann (Eds.) (2006) THESIM: Towards harmonized European statistics on international migration, Louvain-laNeuve, Presses universitaires de Louvain, 746 p.

Ratha Dilip, Mohapatra Sanket and Silwal Ani (2009) Migration and remittance trends 2009, Migration and Development Brief, 11, Washington, World Bank, $14 \mathrm{p}$.

Raymer James and Willekens Frans (Eds.) (2008) International migration in Europe. Data, models and estimates, Chichester, John Wiley, 404 p.

Skeldon Ronald (2010) The current global economic crisis and migration: policies and practice in origin and destination, Working PaperT-32, Development Research Centre on Migration, Globalisation and Poverty, 14 p. 
Sward Jon (2009) Migration and the financial crisis: how will the economic downturn affect migrants?, Development Research Centre on Migration, Globalisation and Poverty, Briefing no.17, Sussex Centre for Migration Research, 4 p.

United Nations (1998) Recommendations on statistics on international migration, Statistical Papers Series M, No. 58, Rev. 1, New York, 96 p.

World Bank (2009) The impact of the economic crisis on migration and remittances, note prepared by Carmen de Paz Nieves, Pierella Paci and Marcin Sasin, [online] consulted 10/01/2012. URL: http://siteresources.worldbank.org/ INTPOVERTY/Resources/3356421251230679308/Impact_of_EconomicCrisis_on_ Migration_and_Remittances.pdf

UNHCR (2010) Asylum levels and trends in industrialized countries, 2009. Statistical overview of asylum applications lodged in Europe and selected nonEuropean countries, Asylum-seekers, $36 \mathrm{p}$. 


\section{Annex}

Total immigration and emigration, observed and estimated figures, 2004-2009*

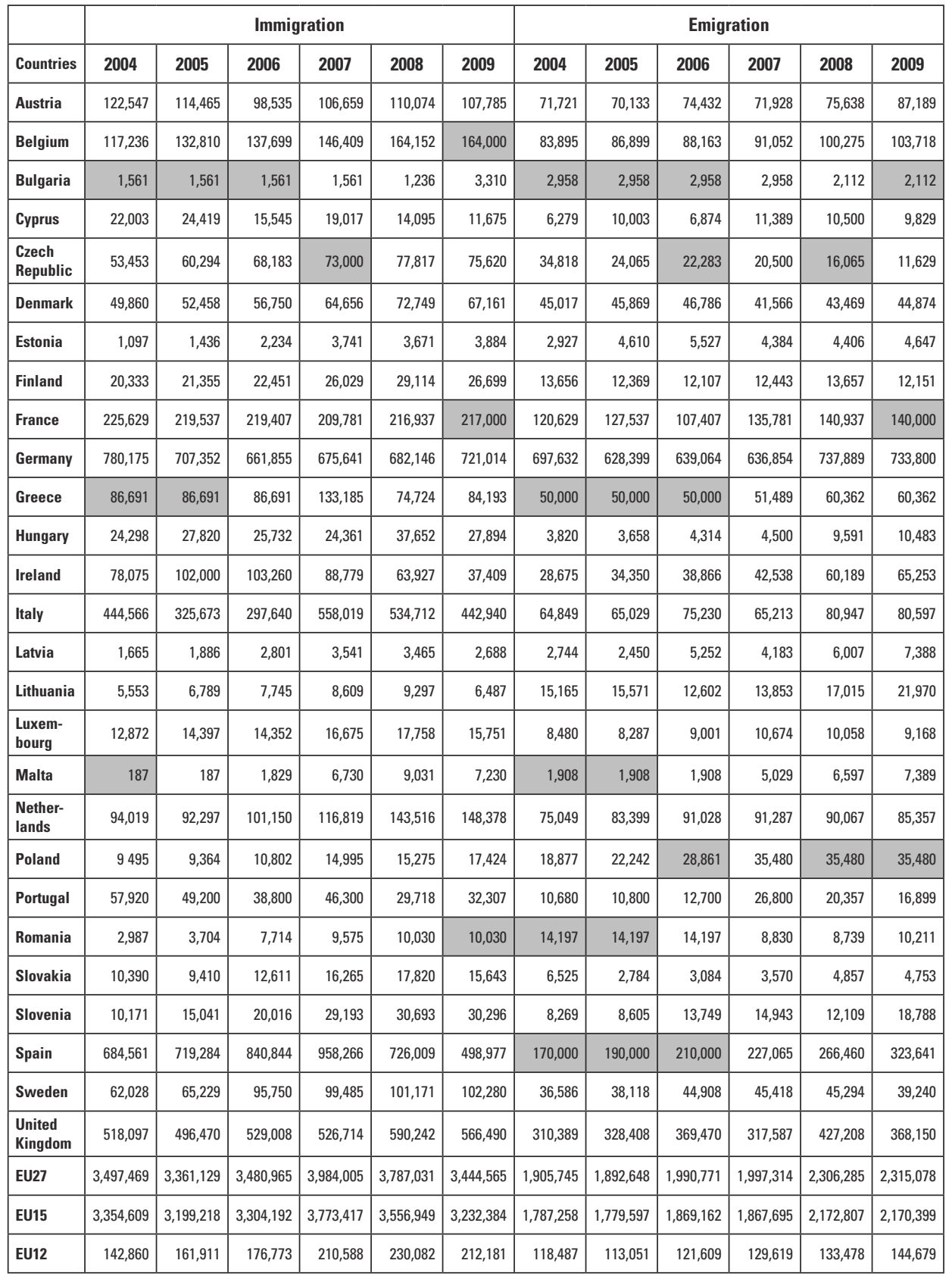

* The figures in the grey cells are estimates based on data from other years used for filling gaps or replacing unreliable data.

Source: Eurostat database and authors' calculations. 


\section{Anne Herm and Michel Poulain}

\section{Economic Crisis and International Migration. What the EU Data Reveal?}

What was the impact of the recent economic crisis on the international migration flows for the European Union? Such crisis may have strengthened the difficulties for non-EU citizens to enter the territory of the EU while the propensity for return migration could have increased. Concerning EU citizens, the impact could be a decreased intra-European mobility and, possibly an increase of extra-European emigration flows. In this contribution we check if data accessible in international and national databases for the year 2007 up to 2009 allow confirming these assumptions. Such analysis has to be carried out very carefully as international migration data are not harmonised despite of efforts done and, they are far to be reliable. Moreover new rules of data collection enforced by the EU since 2008 may have an impact of the newly provided data. Consequently changes in trends observed in 2008 and 2009 in the context of the economic crisis must be dealt with caution as the possible impact of simultaneous changes in data collection may hamper real trends and available data could not be always useful to enlighten the effect of the economic crisis on international migration flows.

\section{Crise économique et migration internationale. Ce que les données de I'UE révèlent?}

Quel a été l'impact de la récente crise économique sur les courants de migration internationale pour I'UE ? Une telle crise pourrait avoir intensifié les difficultés d'immigrer pour les ressortissants des pays tiers alors que la propension au retour de ceux résidant sur le territoire de I'UE pourrait s'être accrue. En ce qui concerne les citoyens européens, l'impact pourrait s'être traduit par une diminution de la mobilité intra-UE et un accroissement de l'émigration hors UE. Dans cette contribution, nous analysons les données accessibles dans les bases de données internationales et nationales afin de vérifier ces hypothèses. Une telle analyse doit être menée avec prudence, car les données de migration internationales ne sont pas encore harmonisées et sont loin d'être fiables. De plus, les nouvelles règles de collecte des données imposées par l'UE depuis 2008 pourraient avoir un effet perturbateur puisque les changements intervenus pourraient cacher les tendances réelles. Ce faisant, on constate que les données disponibles ne sont pas toujours adéquates pour mettre en évidence l'effet de la crise économique sur les migrations internationales. 


\section{Crisis Económica y migración internacional. ¿Qué revelan los datos de la Unión Europea?}

¿Cual ha sido el impacto de la crisis económica reciente sobre los flujos de la migración internacional en la Unión Europea? Una crisis como ésta podría haber intensificado las dificultades de inmigrar para los ciudadanos no pertenecientes a la Unión Europea, así como haber recrudecido la propensión al retorno de los residentes europeos. En relación a los ciudadanos europeos, el impacto podría haber dado lugar a una disminución de la movilidad intra-EU y a un crecimiento de los flujos de emigración extra-EU. En esta contribución, analizamos los datos disponibles en las bases de datos internacionales y nacionales con el fin de verificar estas hipótesis. Este tipo de análisis debe desarrollarse con prudencia ya que los datos de migraciones internacionales no están aún armonizados y están lejos de ser fiables. Además, las nuevas reglas de recolección de datos impuesta por la UE desde 2008 podrían tener un efecto perturbador ya que los cambios introducidos pueden ocultar las tendencias reales. De hecho, se constata que los datos disponibles no son siempre adecuados para poner en evidencia el efecto de la crisis económica sobre las migraciones internacionales. 